Agnieszka Daniluk

Uniwersytet w Białymstoku e-mail: adaniluk@uwb.edu.pl telefon: +48 857457154

DOI: 10.15290/mhi.2014.13.02.15

\title{
Żądanie wyłączenia pracownika organu w postępowaniu administracyjnym w kontekście konkubinatu
}

\author{
SUMMARY \\ Requesting exclusion of an employee in the administrative authority \\ in the context of cohabitation
}

The ideal model of the administrative procedure assumes that public authorities shall proceed in an impartial manner. Exclusion from the administrative proceedings of the entities for which there is reasonable suspicion to act during procedure with an element of bias is a guarantee of objective settlement of the matter. The essence of the exclusion is primarily a permanent elimination of an employee of a particular situation or depriving him of legal possibilities to influence the course of the proceedings and the content issued in the case settlement. The article poses the following questions: does cohabitation justify such an exemption, and what are the consequences of both justified and unjustified exclusion of an employee of administrative body? Analysis of issues for exclusion under the provisions of the Code of Administrative Procedure in the context of cohabitation tends to make some reflections. Firstly, consideration of the evidence in the context of the general is required in the face of increasingly frequent occurrence status of partnerships referred to in Polish nomenclature concubinage. This would provide greater safeguards for the principle of objective truth due to the fact that the process itself off employee would be subject to exclusion from the law, and not at the request of his superior (as it is currently). Second, consideration of the type of legal act for such exclusion as well as the possibility of replacing the provision issued in such cases by other legal act which the measure is the type of management ordinance are required.

Key words: exclusion of an employee, administrative procedure, cohabitation Słowa kluczowe: wyłączenie pracownika, postępowanie administracyjne, konkubinat

Idealny model postępowania administracyjnego zakłada, że organy administracji publicznej prowadzą postępowanie w sposób bezstronny. Przytaczając 
słownikowe ${ }^{1}$ rozumienie tego pojęcia uznać należy, iż postępowanie powinno być prowadzone $\mathrm{w}$ sposób neutralny, niezależny, obiektywny i sprawiedliwy, a organ, podejmując czynności $\mathrm{w}$ celu załatwienia sprawy $\mathrm{w}$ ramach postępowania, zobowiązany jest dokonywać oceny materiału dowodowego, kierując się wyłącznie przepisami prawa i własnym doświadczeniem.

Bezstronność jest właśnie $\mathrm{w}$ taki sposób rozumianą wartością $\mathrm{w}$ europejskim modelu procedury administracyjnej, gdzie w myśl art. 8 Europejskiego Kodeksu Dobrej Praktyki Administracyjnej ${ }^{2}$ organy publiczne działają zgodnie z zasadą bezstronności, kierując się wyłącznie okolicznościami sprawy. W myśl dyspozycji tej normy, organy jak i ich urzędnicy mają obowiązek powstrzymywania się od wszelkich działań, które mogą pozytywnie lub negatywnie oddziaływać na sytuację jednostek. W katalogu czynników, które wpływają na zachwianie bezstronności mieścić się wydają te wynikające z interesów rodzinnych, osobistych, narodowych, jak również wypływające z presji politycznej.

Gwarancją obiektywnego załatwienia sprawy na gruncie postępowania administracyjnego jest instytucja wyłączenia od udziału w postępowaniu podmiotów, co do których występuje uzasadnione podejrzenie wprowadzenia do postępowania elementu stronniczości.

$\mathrm{U}$ podstaw polskiego postępowania administracyjnego w kontekście zasady bezstronności leży norma wyrażona w art. 7 k.p.a., zwana zasadą prawdy obiektywnej. Składa się ona na katalog zasad postępowania administracyjnego, które nazywane są „podstawowymi” (przewodnimi) regułami postępowania i za takie uznawane są przez ustawodawcę ${ }^{3}$. Według B. Adamiak przypisanie normie postępowania zasady ogólnej powoduje różne konsekwencje ${ }^{4}$. Oprócz rozumienia jej jako wytycznej dla wspólnego traktowania całości postępowania administracyjnego, stanowią szczegółowy przejaw konkretyzacji zasad ogólnych, w myśl tezie, że przepisy bardziej szczegółowo muszą być interpretowane z zasadami ogólnymi. Zasady ogólne mogą ponadto służyć do wypełniania ewentualnych luk ${ }^{5} \mathrm{w}$ obrębie k.p.a. W kontekście tych obszarów „,konsekwencji prawnych" rozważeniu poddane zostaną przesłanki wyłączające pracownika od udziału w postępowaniu administracyjnym na gruncie obowiązujących zasad postępowania administracyjnego i ich relacji wobec instytucji konkubinatu.

A. Kubisa-Ślipko, Stownik wyrazów bliskoznacznych, Wałbrzych 2000, s. 12.

2 Europejski Kodeks Dobrej Praktyki Administracyjnej uchwalony został 6 września 2001 r. przez Parlament Europejski.

Z. Janowicz, Postępowanie administracyjne, Warszawa 1987, s. 81.

4 Szerzej: B. Adamiak, J. Borkowski, Kodeks postępowania administracyjnego, wyd. 5, Warszawa 2006, s. 42.

5 Cytując B. Adamiak i S. Rozmaryna, „z punktu widzenia całości KPA taka luka jest tylko pozorna”, S. Rozmaryn, O zasadach ogólnych kodeksu postępowania administracyjnego, „Państwo i Prawo" 1961, nr 12 , s. 889. 
Jedną z najważniejszych gwarancji służących ustaleniu prawdy obiektywnej jest instytucja wyłączenia podmiotów stosujących prawo od załatwienia sprawy indywidualnej. Przedstawiciele doktryny prawa administracyjnego jak również orzecznictwa podkreślają, że u podstaw wyłączenia pracownika leży przede wszystkim wzgląd na konieczność dokonania obiektywnej oceny okoliczności sprawy i sprawiedliwego jej rozstrzygnięcia. Świadczyć ma o tym zarówno konstrukcja przepisów art. $24 \$ 1^{6}$ i $25^{7}$ k.p.a., stanowiących o wyłączeniu $\mathrm{z}$ mocy prawa - $\mathrm{w}$ przypadku zaistnienia określonych przesłanek - pracownika lub organu, nie uzależniając tego skutku od występowania $\mathrm{w}$ sprawie kilku stron o sprzecznych żądaniach (spornych interesach), jak również konstrukcja przepisu art. 24 §3 k.p.a. ${ }^{8}$, która dopuszcza możliwość wyłączenia pracownika z urzędu. Przesłanki te wskazują na bliskość pracownika wobec stron postępowania bądź na bliskość załatwianej sprawy.

Wyłączenie od udziału w postępowaniu polega jedynie na utracie zdolności prawnej przez poszczególnych pracowników do podejmowania określonych czynności procesowych $\mathrm{w}$ danej sprawie ${ }^{9}$. Istotą wyłączenia jest przede wszystkim trwałe wyeliminowanie pracownika z konkretnej sytuacji, czyli pozbawienie go prawnych możliwości wpływu na przebieg postępowania i treść wydanego $\mathrm{w}$ tej sprawie rozstrzygnięcia.

Przesłanki z art. $24 \$ 1$ obejmują trzy różne płaszczyzny. Pierwsze trzy odnoszą się do osobistych więzi pracownika prowadzącego sprawę, będących wynikiem konkretnych stosunków społecznych, w tym stosunków prawnych, takich jak: małżeństwo, pokrewieństwo, przysposobienie, kuratela lub

6 Art. 24 §1 k.p.a.: „Pracownik organu administracji publicznej podlega wyłączeniu od udziału $\mathrm{w}$ postępowaniu $\mathrm{w}$ sprawie: 1) $\mathrm{w}$ której jest stroną albo pozostaje $\mathrm{z}$ jedną ze stron $\mathrm{w}$ takim stosunku prawnym, że wynik sprawy może mieć wpływ na jego prawa lub obowiązki, 2) swego małżonka oraz krewnych i powinowatych do drugiego stopnia, 3) osoby związanej z nim z tytułu przysposobienia, opieki lub kurateli, 4) w której był świadkiem lub biegłym albo był lub jest przedstawicielem jednej ze stron, albo w której przedstawicielem jednej strony jest jedna z osób wymienionych w pkt 2 i 3,5) w której brał udział w niższej instancji w wydaniu zaskarżonej decyzji, 6) z powodu której wszczęto przeciw niemu dochodzenie służbowe, postępowanie dyscyplinarne lub karne, 7) w której jedną ze stron jest osoba pozostająca wobec niego w stosunku nadrzędności służbowej".

7 Art. 25 k.p.a.: „§ 1. Organ administracji publicznej podlega wyłączeniu od załatwienia sprawy dotyczącej interesów majątkowych: 1) jego kierownika lub osób pozostających z tym kierownikiem w stosunkach określonych w art. $24 \S 1$ pkt 2 i 3, 2) osoby zajmującej stanowisko kierownicze $\mathrm{w}$ organie bezpośrednio wyższego stopnia lub osób pozostających z nim w stosunkach określonych w art. $24 \S 1$. pkt 2 i 3 . $\S 2$. Przepis art. $24 \S 4$ stosuje się odpowiednio".

8 Art. 24 §3: „Bezpośredni przełożony pracownika jest obowiązany na jego żądanie lub na żądanie strony albo z urzędu wyłączyć go od udziału w postępowaniu, jeżeli zostanie uprawdopodobnione istnienie okoliczności nie wymienionych w § 1., które mogą wywołać wątpliwość co do bezstronności pracownika".

9 W. Chróścielewski, Gmina jako strona postępowania administracyjnego - konsekwencje prawne uchylenia art. 27 a kpa, „Samorząd Terytorialny” 1995, nr 4, s. 21. 
opieka. Przesłanki czwarta i piąta mają charakter procesowy i dotyczą przede wszystkim stosunku pracownika do uczestników postępowania lub do organu prowadzącego sprawę. Ostatnie dwie przesłanki mają charakter stosunku pracowniczego.

Nieco inną konstrukcję ma art. 24 §3 k.p.a., który stanowi o istnieniu innych okoliczności niż wyżej wymienione, które mogą wywołać wątpliwości co do bezstronności pracownika. Przepis ten wydaje się być dopełnieniem zamkniętego katalogu przesłanek wyłączenia. W założeniu ustawodawcy daje on możliwość przeciwdziałania nadużyciom mogącym powstać na skutek stronniczego załatwienia sprawy, w przypadku gdy wystąpią okoliczności niewymienione $\mathrm{w}$ art. $24 \S 1$ k.p.a., a jednak zagrażające sprawiedliwemu, rzetelnemu uczciwemu przeprowadzeniu czynności procesowych. Czy jednak art. 24 §3 zapewnia w pełni realizację tego celu?

Podstawową różnicą pod względem okoliczności wymienionych w obu powyższych artykułach jest wyłączenie pracownika na mocy art. $24 \S 1$ k.p.a. bez potrzeby wykazania, że przyczyny te mogłyby wywołać wątpliwości co do bezstronności. W przypadku zaś art. 24 §3 k.p.a. przesłanką wyłączenia pracownika przez bezpośredniego przełożonego jest konieczność uprawdopodobnienia, że istnienie tych okoliczności może wywołać wątpliwości co do bezstronności pracownika. Użycie przez ustawodawcę określenia "uprawdopodobnienie" daje szerokie możliwości wyłączenia pracownika, względem którego sformułowane zostanie samo podejrzenie o braku bezstronności (a dokładnie - wystąpią okoliczności, które "mogą wywołać wątpliwości co do bezstronności”). Zdaniem NSA nawet „nie jest konieczne uprawdopodobnienie, że pracownik będzie stronniczy w załatwieniu sprawy ze względu na daną okoliczność, lecz wystarczy, że okoliczność ta powoduje powstanie wątpliwości co do jego bezstronności, a zatem nie jest pewne i jasne, czy pracownik wykona swoje uprawnienia procesowe w sposób bezstronny"10.

Powodem braku bezstronności pracownika może być albo jego stosunek do sprawy, bądź osobisty stosunek do jednej ze stron. Okolicznościami, których prawdopodobieństwo uzasadnia wyłączenie pracownika na podstawie tego artykułu mogą być zarówno okoliczności będące źródłem (przyczyną) powstania jego stosunku do strony lub do sprawy, jak i okoliczności będące przejawem (skutkiem) istnienia takiego stosunku ${ }^{11}$.

„Stosunek osobisty może mieć charakter emocjonalny lub racjonalny. Stosunek natury emocjonalnej polega na mniej lub bardziej uzasadnionym «obiektywnie» odczuwaniu sympatii lub antypatii do drugiej osoby. Stosunek o charakterze racjonalnym oznacza istnienie powiązań (np. gospodarczych, ekono-

10 Wyrok NSA z 18 kwietnia 2012 r., II OSK, 40/20, LEX nr 1219149.

11 Z. Kmiecik, Żądanie wyłączenia pracownika organu w postępowaniu administracyjnym, „Przegląd Prawa Publicznego" 2009, nr 3, s. 67. 
micznych) wpływających (wzajemnie lub jednostronnie) na interesy lub pozycję życiową drugiej osoby"12.

W związku z analizowanym zagadnieniem odpowiedzi wymaga pytanie, czy w sytuacji konkubinatu występuje tylko stosunek osobisty o emocjonalnym zabarwieniu, czy też stosunek nazwany jak powyżej o charakterze „racjonalnym". Jeżeli tak, to w jaki sposób podlega on weryfikacji. Czy fakt ustania konkubinatu jest okolicznością uzasadniającą wyłączenie i jakie są skutki zarówno uzasadnionego, jak i nieuzasadnionego wyłączenia pracownika organu z uwagi na tę okoliczność.

Pojęcie konkubinatu stosowane jest do określenia faktycznego trwałego pożycia kobiety i mężczyzny, charakteryzującego się występowaniem takich więzi, jakie cechują pożycie małżonków, bez formalizowania tego związku przez zawarcie małżeństwa ${ }^{13}$. Można określić go jako naturalny związek dwóch osób podobny do instytucji małżeństwa, jednak nieformalny z uwagi na brak rejestracji cywilnej lub religijnego usankcjonowania związku. Skoro zatem uznaje się go za naturalny związek dwóch osób podobny do instytucji małżeństwa, analizy wymagać wydają się płaszczyzny owego podobieństwa.

W Polsce nie ma możliwości rejestrowania konkubinatów, z czego z kolei wynikają inne konsekwencje prawne na gruncie prawa cywilnego. Jedną z nich jest brak możliwości praktycznego dochodzenia praw spadkowych (z wyłączeniem dziedziczenia z testamentu) czy alimentacyjnych dla konkubenta. Ograniczenia wynikające $\mathrm{z}$ pozostawania $\mathrm{w}$ konkubinacie uniemożliwiają wspólne przysposobienie dziecka czy wspólne sprawowanie funkcji opiekuna ${ }^{14}$.

12 Ibidem, s. 67.

13 Na temat pojęcia konkubinatu zob. W. Ćwiek, Konkubinat, Warszawa 2002, s. 2-9.

$14 \mathrm{~W}$ prawie administracyjnym do zagadnienia konkubinatu ustawodawca odnosi się pośrednio w ustawie z 29 września 1986 r. - Prawo o aktach stanu cywilnego (t.j. Dz. U. z 2004 r., nr 161, poz. 1688 z późn. zm.) oraz w rozporządzeniu Ministra Spraw Wewnętrznych i Administracji z 26 października 1998 r. w sprawie szczegółowych zasad sporządzania aktów stanu cywilnego, sposobu prowadzenia ksiąg stanu cywilnego, ich kontroli, przechowywania i zabezpieczenia oraz wzorów aktów stanu cywilnego, ich odpisów, zaświadczeń i protokołów (Dz. U. nr 136, poz. 884 z późn. zm.). Regulacje w zakresie tej problematyki mają także miejsce w ustawie z 17 października 2008 r. o zmianie imienia i nazwiska (Dz. U. nr 220, poz. 1414) czy ustawie z 29 lipca 2005 r. o przeciwdziałaniu przemocy w rodzinie (Dz. U. nr 180, poz. 1493 z późn. zm.). Ponadto należy także wskazać inne akty normatywne, tj. ustawę z 26 października 1982 r. o postępowaniu w sprawach nieletnich (t.j. Dz. U. z 2010 r., nr 33, poz. 178), ustawę z 13 lutego 1984 r. o funkcjach konsulów Rzeczypospolitej Polskiej (t.j. Dz. U. z 2002 r., nr 215, poz. 1823 z późn. zm.), rozporządzenie Ministra Finansów z 5 czerwca 2001 r. w sprawie zasad i trybu składania przez opiekuna w instytucji bankowej gotówki osoby pozostającej pod opieką (Dz. U. nr 64, poz. 649), ustawę z 27 lipca 2001 r. o kuratorach sądowych (Dz. U. nr 98, poz. 1071 z późn. zm.), ustawę z 12 marca 2004 r. o pomocy społecznej (t.j. Dz. U. z 2009 r., nr 175, poz. 1362 z późn. zm.) oraz następujące akty wykonawcze do tej ustawy: rozporządzenie Ministra Polityki Społecznej z 5 października 2004 r. w sprawie centralnego banku danych o dzieciach oczekujących na przysposobienie oraz ośrodków adopcyjno-opiekuńczych upoważnionych do współpracy z licencjonowanymi przez rządy innych państw organizacjami lub ośrodkami adopcyjnymi (Dz. U. nr 223, poz. 2266), rozporządzenie Mi- 
Współwłasność majątkowa konkubentów może natomiast powstać tylko na ogólnych zasadach prawa cywilnego. Przyjmuje się, że podstawę roszczeń majątkowych stanowią wzajemne porozumienia, nazywane umowami konkubenckimi. W doktrynie podkreśla się, że zasadnicza różnica między umowami konkubenckimi a zwykłymi umowami majątkowymi wynika z założenia, że w sytuacji konkubinatu dochodzi do formowania się stosunków osobistych, podczas gdy w umowach majątkowych - podstawowym założeniem jest osiągniecie celu gospodarczego ${ }^{15}$. Okoliczności te powodują, że następuje zmiana w terminologii określania osób znajdujących się w stanie konkubinatu. Samo słowo konkubinat coraz częściej zastępowane jest słowem kohabitacja ${ }^{16}$, zaś mówiąc o konkubencie czy o konkubinie coraz powszechniej używane jest sformułowanie "osoby pozostające ze sobą w faktycznym pożyciu"17. Użycie takiego określenia wydaje się iż powinno wpływać na ułatwienie ustalenia powiązań stosunków osobistych $\mathrm{z}$ majątkowymi przy jednoczesnym istnieniu więzi fizycznej i wspólnym mieszkaniu osób żyjących w konkubinacie. Czyż bowiem $\mathrm{w}$ relacji konkubentów nie istnieją powiązania gospodarcze i ekonomiczne, wpływające na interesy lub pozycję życiową drugiej osoby? Odpowiedź na tak postawione pytanie wydaje się być jednoznaczna. Skoro przyjmujemy, że jest to relacja pomiędzy dwojgiem ludzi oparta na założeniach instytucji małżeństwa, a z uwagi na fakt braku możliwości jej zarejestrowania nie posiada regulacji prawnej, to jest to bardziej skutek, a nie cecha tej relacji. W obliczu powyższego można ją zatem uznać za posiadającą stosunek osobisty zarówno natury emocjonalnej, jak i racjonalnej.

W świetle art. 24 §3 k.p.a. podstawą wyłączenia pracownika nie powinno być subiektywne wrażenie strony, lecz jedynie konkretne fakty. Kwestia zweryfikowania faktu pozostawania w stosunku osobistym często nie jest do końca możliwa. Wydaje się zatem, że użycie określenia uprawdopodobnienia okoliczności, które mogą wywołać wątpliwości co do bezstronności pracownika zastosowano celowo, aby ograniczyć proces dowodzenia, a tym samym zabezpieczyć interes prawny strony postępowania. Chodzi tu bowiem o okoliczności, które w powszechnym odczuciu usprawiedliwiają przypuszczenie, że pracownik przy rozpatrywaniu sprawy i jej rozstrzyganiu będzie zachowywać się

nistra Polityki Społecznej z 18 października 2004 r. w sprawie rodzin zastępczych (Dz. U. nr 233, poz. 2344 z późn. zm.), rozporządzenie Ministra Pracy i Polityki Społecznej z 4 czerwca 2010 r. w sprawie ośrodków adopcyjno-opiekuńczych (Dz. U. nr 110, poz. 733), a także rozporządzenie Ministra Pracy i Polityki Społecznej z 19 października 2007 r. w sprawie placówek opiekuńczo-wychowawczych (Dz. U. nr 201, poz. 1455); także ustawę z 7 września 2007 r. o pomocy osobom uprawnionym do alimentów (t.j. Dz. U. z 2009 r., nr 1, poz. 7 z późn. zm.)

K. Slany, Alternatywne formy życia małżeńsko-rodzinnego w nowoczesnym świecie, Kraków 2002, s.

16 W. Ćwiek, op. cit., s. 56.

17 Podobnie w rozumieniu prawa karnego konkubenci są dla siebie osobami najbliższymi, co rodzi pewne skutki w postępowaniu karnym (np. możliwość odmowy zeznań wobec konkubenta). 
stronniczo ${ }^{18}$. Z drugiej jednak strony, dlaczego fakt pozostawania w konkubinacie nie jest sklasyfikowany w $\S 1$ pkt 2, który w sposób bezpośredni odnosi się do więzi natury osobistej? Fakt definiowania konkubinatu w prawie polskim jako relacji opartej na założeniach instytucji małżeństwa bez usankcjonowania jej w prawie, wydaje się przemawiać za potrzebą jej regulacji w sposób bardziej wyraźny. W kategorii przesłanek, w których dopatruje się istnienia stosunku o charakterze emocjonalnym przedstawiciele doktryny $\mathrm{w}$ jednym zdaniu wymieniają następujące okoliczności: utrzymywanie ze stroną kontaktów intymnych, mogących świadczyć o łączącym ich uczuciu miłości, jak i kontakty towarzyskie, świadczące o łączących ich więziach przyjaźni czy bliższej znajomości ${ }^{19}$. Zestawienie obu tych przesłanek może prowadzić do licznych nieporozumień. Podstawą do wyłączenia pracownika nie będzie sam fakt znajomości przez niego strony lub jej osoby bliskiej. Trudno bowiem w małej gminie postawić urzędnikowi zarzut znajomości strony postępowania, zwłaszcza gdy najczęściej taki pracownik organu zna większość społeczności lokalnej. Drugim zastrzeżeniem przy interpretacji w powyższy sposób przepisu art. 24 §3 jest okoliczność utrzymywania stosunków intymnych. Uwzględniając stanowisko doktryny w oparciu o powyższe dywagacje, często przesłanka ta nie ma natury relacji o charakterze trwałym, z której wynikałby stosunek osobisty o charakterze emocjonalnym i racjonalnym, jak ma to miejsce $\mathrm{w}$ przypadku konkubinatu. Zestawienie $\mathrm{w}$ jednym rzędzie obu tych okoliczności o zupełnie innym ciężarze gatunkowym problemu wydaje się świadczyć o ignorancji ustawodawcy w zakresie dostrzegania potrzeby oddzielnej regulacji stanu konkubinatu. Zarówno okoliczność nazwana jako utrzymywanie ze stroną kontaktów intymnych, czy też kontaktów towarzyskich nie muszą przecież spełniać cech, przez które konkubinat jest definiowany.

Bez względu jednak na rodzaj tego stosunku uwzględnienie wniosku o wyłączenie pracownika zależy od uznania przełożonego. $Z$ faktem tym z kolei ${ }^{20}$ nierozłącznie wiążą się skutki nieuzasadnionego wyłączenia pracownika organu. Zasadniczo, wyłączenie pracownika organu pociąga za sobą jedynie konieczność wyznaczenia innego pracownika do prowadzenia sprawy, do czego zobowiązany jest bezpośredni przełożony wyłączonego pracownika. W przy-

18 Wyrok WSA w Bydgoszczy z 7 marca 2012 r., II SA/Bd 47/12, LEX nr 1138341. Przepis art. $24 \S 3$ k.p.a. ma charakter gwarancyjny - służyć ma zapewnieniu bezstronnego wykonywania czynności w postępowaniu administracyjnym. Jego istotą jest eliminacja nawet jedynie potencjalnych wątpliwości co do braku bezstronności pracownika organu czy biegłego. Dla zastosowania art. 24 §3 k.p.a. wystarczy uprawdopodobnienie istnienia okoliczności mogących wywoływać wątpliwość co do bezstronności, a nie okoliczności powodujących stronniczość. Wystarczy zatem, że z uwagi na konkretną okoliczność nie jest pewne i jasne, czy dana czynność procesowa zostanie wykonana w sposób bezstronny.

20 L. Żukowski, [w:] Ł. Żukowski, R. Sawuła, Postępowanie administracyjne i postępowanie przed Naczelnym Sądem Administracyjnym, Warszawa 2002, s. 45. 
padku wyłączenia członka organu kolegialnego taki skutek wystąpi, gdy wyłączenie pracownika wiązałoby się z utratą przez organ kworum niezbędnego do podjęcia uchwały. Skutkiem wyłączenia pracownika tworzącego organ monokratyczny będzie załatwienie sprawy przez organ wyższego stopnia nad tym organem. $\mathrm{Z}$ tego też powodu przesłanki uzasadniające wyłączenie pracownika powinny być badane ze szczególną wnikliwością. Skoro bowiem wyłączenie pracownika powoduje poddanie załatwienia sprawy przez inny organ, to nieuzasadnione wyłączenie, a w konsekwencji przeniesienie sprawy do innego organu, będzie mogło spotkać się z zarzutem wydania rozstrzygnięcia przez organ niewłaściwy. Zastrzec jednak należy, że takie sytuacje należą do rzadkości.

Co do zasady, nadmiar „ostrożności procesowej” wyrażający się w wyłączeniu pracownika, choć nie było ku temu żadnych podstaw prawnych, na ogół nie pociąga za sobą żadnych negatywnych konsekwencji ani procesowych, ani materialnych ${ }^{21}$. W przypadku jednak bezpodstawnego przekazania sprawy innemu organowi z powołaniem się na jedną z ustawowych przesłanek wyłączenia, należy poddać w wątpliwość jego zasadność w przypadku, gdy przekazanie sprawy innemu organowi jest konsekwencją bezzasadnego wyłączenia pracownika organu na podstawie przyczyny w art. $24 \$ 3$ k.p.a. Wyłączenie to, jak już wyżej zostało wspomniane, następuje na mocy postanowienia uprawnionego podmiotu. W doktrynie panuje jednak spór co do uznania za konieczne wydanie w tej sprawie postanowienia. Cytując za E. Pierzchałą, „Nawet gdyby założyć, że wydanie takiego postanowienia jest niezbędne ze względów dowodowych, co nota bene można uzyskać w drodze odpowiedniego wpisu do protokołu, to postanowienie takie mogłoby mieć jedynie charakter deklaratywny. Oznacza to, że na przyczyny wyłączenia pracownika od udziału $\mathrm{w}$ postępowaniu można się powoływać $\mathrm{z}$ chwilą ich zaistnienia, a nie $\mathrm{z}$ chwilą uprawomocnienia się postanowienia o wyłączeniu" ${ }^{22}$. Postanowienie zaś nie może ograniczać się do wskazania pracownika wyłączonego z mocy prawa od udziału w postępowaniu, lecz powinno wyznaczać innego pracownika do prowadzenia sprawy. W tym trybie nie jest dopuszczalne orzeczenie o odmowie wyłączenia pracownika $\mathrm{z}$ uwagi na fakt, iż postanowienie to wydawane jest $\mathrm{z}$ urzędu. Wniosek strony lub pracownika $\mathrm{w}$ tym zakresie nie jest wnioskiem o wydanie postanowienia, lecz jest czynnością innego rodzaju ${ }^{23}$. Czynność wyłączenia wydaje się zatem mieć charakter stricte pracowniczy, o czym świadczy fakt, iż to przełożony, bezpośrednio usytuowany w stosunku nadLublin 2010, s. 633-634.

23 ków 2005, s. 208. 
rzędności służbowej, powinien zabezpieczyć wykonywanie zadań w ramach danego stanowiska pracy.

Pracownik wyłączony od udziału w postępowaniu, niezależnie od podstawy wyłączenia, powinien zaniechać prowadzenia czynności procesowych $\mathrm{w}$ sprawie, z wyjątkiem czynności niecierpiących zwłoki ze względu na interes społeczny lub ważny interes stron. $\mathrm{W}$ zakresie tych czynności, powtarzając za J. Borkowskim, mieszczą się „czynności, które muszą być podjęte z powodu treści obowiązujących przepisów, ustanawiających nieprzekraczalny termin do dokonania określonych czynności, z uwagi na skutki orzeczeń administracyjnych lub sądowych, utratę uprawnień, niemożność wyegzekwowania w późniejszym czasie określonych obowiązków stron czy też ze względu na okoliczności faktyczne, narzucające potrzebę pilnego działania". Do czasu, gdy postanowienie nie zostanie uchylone obowiązują skutki jego zastosowania, a organ pozostaje niezdolny do załatwienia sprawy. Z uwagi na fakt, iż postanowienie to nie podlega zaskarżeniu, to stworzony $w$ nim stan prawny jest niewzruszalny i brak jest możliwości dokonania oceny, czy wyłączenie takie było uzasadnione czy nie ${ }^{24}$.

Przy przyjęciu założenia, że dopuszczalne byłoby uchylenie postanowienia o wyłączeniu, jednocześnie możliwe byłoby także jego unieważnienie. W konsekwencji pozbawiałoby go skutków prawnych z mocą wsteczną, a to zaś dopiero otwierałoby drogę do stwierdzenia nieważności decyzji wydanej przez inny organ ze względu na niewłaściwość tego organu.

W literaturze ${ }^{25}$ krytyce poddana jest rozbieżność pomiędzy brzmieniem art. 24 k.p.a. a $145 \S 1$ pkt 3 k.p.a., polegająca na tym, że zgodnie z treścią art. 24 wyłączenie pracownika następuje "od udziału w postępowaniu”, zaś treść dotycząca wznowienia postępowania głosi: „w sprawie zakończonej decyzją ostateczną wznawia się postępowanie, jeżeli: §6 pkt 3 decyzja została wydana przez pracownika, który podlega wyłączeniu...". W zakresie pojęcia udziału w postępowaniu mieścić się będą czynności polegające na podejmowaniu czynności przygotowawczych przed wydaniem decyzji, samo wydanie takiej decyzji, jak i czynności od jej wydania. Krytyka powyższego rozwiązania nie wydaje się być, zdaniem Z. R. Kmiecika ${ }^{26}$, uzasadniona. Zdaniem autora zauważyć należy, że „gdyby przesłanka wznowienia, o której mowa w art. 145 § 1 pkt 3 kpa była określona jako «udział w postępowaniu» pracownika podlegającego wyłączeniu, to jej gramatyczna wykładnia nakazywałaby podciągnąć pod nią również przypadki absolutnie nie uzasadniające potrzeby wznowienia postępowania". Taka sytuacja mogłaby mieć miejsce wówczas, gdy wątpliwości co do bezstronności pracownika, o których głosi art. 24 §3 k.p.a., powstałyby 
dopiero po przeprowadzeniu przez niego części postępowania dowodowego, w związku z czym został on wyłączony od udziału w postępowaniu, zaś wyznaczony inny pracownik organu przeprowadził powtórnie wadliwe postępowanie dowodowe.

Podlegający wyłączeniu pracownik, który brał udział w postępowaniu $\mathrm{w}$ danej sprawie lub też sprawa taka została załatwiona przez wyłączony organ, są poza zakresem art. $145 \S 1$ pkt 3 k.p.a. Wyłączenie pracownika, zdaniem W. Chróścielewskiego ${ }^{27}$, „nie wymaga powtórzenia wszystkich czynności postępowania, w których brał on udział", a tym samym przeprowadzenia postępowania wyjaśniającego w całości lub znacznej części.

Podobnie wznowienie postępowania ze względu na jakikolwiek „udział w postępowaniu" pracownika podlegającego wyłączeniu nie byłoby zasadne również wówczas, gdy wada taka została skorygowana w postępowaniu odwoławczym (przekazanie decyzji organowi I instancji do ponownego rozpatrzenia).

Jednak z uwagi na fakt, że na to postanowienie zaskarżenie nie przysługuje, zastanowienia wydaje się wymagać kwestia, czy forma wyłączenia na mocy postanowienia jest jedynym rodzajem aktu i w kontekście powyższych uwag - czy spełnia swoją rolę. Na tak postawione pytania, moim zdaniem, należy odpowiedzieć negatywnie. Aktem prawnym, który w pełni skutecznie uzyskałby ten sam cel i mógłby owo postanowienie zastąpić jest zarządzenie. Zarządzenie jako akt normatywny o charakterze wewnętrznym jest aktem kierownictwa i stosowanie go w stosunkach pracowniczych jest jak najbardziej pożądane i uzasadnione ${ }^{28}$. Okoliczności te przemawiają za wprowadzeniem zarządzenia $\mathrm{w}$ miejsce postanowienia. $\mathrm{Z}$ całą pewnością taki akt normatywny nie budziłby wątpliwości co do swojej konstrukcji prawnej i spełnianego celu.

Analiza problematyki wyłączenia na mocy art. 24 §3 k.p.a. w kontekście konkubinatu skłania do poczynienia kilku refleksji. Po pierwsze, w obliczu coraz częstszego stanu występowania związków partnerskich, określanych w polskiej nomenklaturze konkubinatem, zastanowienia wymaga uwzględnienie tej przesłanki w ramach przesłanek ogólnych, wynikających z art. 24 §1 k.p.a. Spowodowałoby to wzmocnienie gwarancji realizacji zasady prawdy obiektywnej $\mathrm{z}$ uwagi na fakt, iż sam proces wyłączania pracownika podlegałby wyłączeniu z mocy prawa, a nie na wniosek przełożonego. Fakt literalnego zapisu zniósłby wszelkie wątpliwości co do dywagacji w sferze relacji osobistych o charakterze racjonalnym czy emocjonalnym. Zestawienie konkubinatu ze znajomością jako okoliczność mogąca powodować wyłączenie pracownika zaburza moim zdaniem przejrzystość intencji ustawodawcy. Trudno bowiem w jednym przepisie

27 W. Chróścielewski, Organ administracji publicznej w postępowaniu administracyjnym, Warszawa 2002, s. 90-91.

28 J. Boć, Prawo administracyjne, Wrocław 2007, s. 81. 
uregulować te dwie, mające inne źródło pochodzenia, podstawy do wyłączenia pracownika. Po drugie, na podstawie dokonanej analizy zmiany wymaga rodzaj aktu wyłączenia i zastąpienie postanowienia innym aktem normatywnym, mającym charakter aktu kierownictwa typu zarządzenie.

\section{Bibliografia}

\section{Literatura}

Adamiak B., Borkowski J., Kodeks postępowania administracyjnego, wyd. 5, Warszawa 2006.

Boć J., Prawo administracyjne, Wrocław 2007.

Ćwiek W., Konkubinat, Warszawa 2002.

Chróścielewski W., Gmina jako strona postępowania administracyjnego - konsekwencje prawne a uchylenia art. 27 a kpa, "Samorząd Terytorialny” 1995, nr 4.

Chróścielewski W., Organ administracji publicznej w postępowaniu administracyjnym, Warszawa 2002.

Janowicz Z., Postępowanie administracyjne, Warszawa 1987.

Kmiecik Z., Żąanie wyłaczenia pracownika organu w postępowaniu administracyjnym, „Przegląd Prawa Publicznego" 2009, nr 3.

Kubisa-Ślipko A., Słownik wyrazów bliskoznacznych, Wałbrzych 2000.

Pierzchała E., [w:] Kodyfikacja postępowania administracyjnego na 50-lecie KPA, red. J. Niczyporuk, Lublin 2010.

Rozmaryn S., O zasadach ogólnych kodeksu postępowania administracyjnego, „Państwo i Prawo" 1961, nr 12.

Slany K., Alternatywne formy życia matżeńsko-rodzinnego w nowoczesnym świecie, Kraków 2002.

Wróbel A., [w:] M. Jaśkowska, A. Wróbel, Kodeks Postępowania Administracyjnego. Komentarz, Kraków 2005.

Żukowski L., [w:] Ł. Żukowski, R. Sawuła, Postępowanie administracyjne i postępowanie przed Naczelnym Sądem Administracyjnym, Warszawa 2002.

\section{Orzecznictwo}

Wyrok NSA z 18 kwietnia 2012 r., II OSK, 40/20, LEX nr 1219149.

Wyrok WSA w Bydgoszczy z 7 marca 2012 r., II SA/Bd 47/12, LEX nr 1138341. 